\section{PENELITIAN PENGARUH CUACA TERHADAP SIFAT TEGANGAN PUTUS, PERPANJANGAN PUTUS DAN KEKERASAN SOL KARET CETAK DENGAN ALAT WEATHER - OMETER.}

\section{Oleh : Hadi Musthofa}

\section{ABSTRACT}

The aim of this research is to find out the effect of weathering exposure on the quality of moulding rubber sole by weather - ometer apparatus (in door weathering test). During indoor test by Weather - Ometer, the condition of research is kept constanly i.e. black panel at $50^{\circ} \mathrm{C}$, dry bulb at $36^{\circ} \mathrm{C}$, wet bulb at $26^{\circ} \mathrm{C}$ and humidity at $45 \%$.

Specimen exposed taking over from the chamber for testing purpose were caried out every 25 hours and performed up to the limiting time at which specific physical properties change of the sample come out. The highest change of the speciments physical properties happened at the treatment of 100 hours, 125 hours and 150 hours.

\section{INTISARI}

Penelitian ini bertujuan untuk mengetahui pengaruh cuaca terhadap mutu sol karet cetak dengan alat Weather - Ometer (secara indoor). Dalam melaksanakan penelitian dengan alat Weather - Ometer kondisi selama penelitian dipertahankan yaitu dengan black panel pada $50^{\circ} \mathrm{C}$, dry bulb $36^{\circ} \mathrm{C}$, wet bulb $26^{\circ} \mathrm{C}$ dan kelembapan udara sebesar $45 \%$.

Pengambilan cuplikan yang telah terkena penyinaran dari dalam alat untuk diuji dilaksanakan tiap 25 jam sekali, hal ini dilakukan sampai batas waktu dimana terjadi perubahan sifat fisika contoh uji. Perubahan sifat fisika terbesar terjadi pada perlakuan 100 jam, 125 jam dan 150 jam. \section{8}

Majalah Barang Kulit, Karet dan Plastik

\section{Pendahuluan}

Sol karet cetak merupakan salah satu komponen yang dipakai dalam pembuatan sepatu, dan umumnya dalam penggunaanya langsung terpengaruh oleh cuaca, hal ini dapat menyebabkan terjadinya perubahan sifat fisis dari sol karet cetak tersebut.

Untuk mengetahui sampai seberapa jauh pengaruh cuaca terhadap sol karet cetak, maka perlu kiranya diadakan suatu penelitian tentang pengaruh cuaca terhadap sifat fisika sol karet cetak. Pengaruh cuaca terhadap barang karet telah diselidiki CrabTree dan Cram yang hasilnya bahwa suatu oksidasi terhadap barang karet dapat dipercepat oleh adanya cahaya. Adanya serangan ozon yang terkandung dalam udara dapat menyebabkan terjadinya perubahan tegangan dari barang-barang karet

Menurut Van Rossen dan Tallen pengaruh cuaca terhadap barang karet sebagai berikut :

- Penyebab retak pada barang karet akan semakin melebar dengan adanya serangan ozon.

- Cahaya mempuyai peranan penting pada pembentukan retak-retak terutama pada bagian yang langsung terkena penyinaran akan terjadi suatu oksidasi.

- Ozon udara buatan dapat menghasilkan retak yang keadaannya sama dengan udara luar dan hanya besarnya ditentukan oleh kandungan dari masingmasing bahan seperti halnya $\mathrm{NO}_{2}, \mathrm{SO}_{2}, \mathrm{Cl}$.

- Pengaruh derajat vulkanisasi pada pembentukan retak-retak dapat menyebabkan turunnya sifat mekanik.

Penambahan asam stearat kedalam kompon karet dapat bertungsi sebagai pelindung dalam waktu yang relatif singkat dari pengaruh lingkungan, dengan demikian asam stearat hanya sedikit berpengaruh terhadap adanya perbaikan sifat

Pembentukan retak-retak dapat terjadi dalam styrene butadiene rubber 94 yang disebabkan oleh kandungan ozon dalam udara lebih besar dari pada pengaruh cahaya :. Terjadinya tanda retak-retak tersebut dapat juga disebabkan karena dispersi (penyebaran) bahan pengisi yang berupa karbon black dalam campuran kurang homogen , dengan adanya penambahan faslin, parafin, coroserina, ozocarite memperlihatkan bahwa potongan uji karet mempunyai ketahanan selama empat minggu tidak mengalami retak-retak, namun demikian adanya ozon dengan kadar $0,003 \%$ merupakan ambang batas untuk konsentrasi ozon terhadap faslin, parafin, carosine, dan ozocarite yang berfungsi sebagai pelindung

Pengaruh pemberian bahan pelunak kedalam kompon karet terhadap pembentukan retak-retak, maka pada bagian yang kena sinar matahari pengaruh dari

Vol. IX No. 16 Tahun 1993/1994 
oksidasi terlihat sangat jelas.

Adapun penelitian yang dilaksanakan disini dengan menggunakan alat Weather -Ometer yang kondisi percobaannya dapat diatur sesuai dengan yang diinginkan.

Materi Dan Metode Penelitian

Materi penelitian terdiri dari :

1. Bahan

Bahan yang diperlukan dalam penelitian ini berupa sol karet cetak yang langsung diperoleh dari hasil uji petik keperusahaan yang memproduksi sepatu.

2. Alat untuk menunjang penelitian berupa :

- alat pembentuk specimen

- alat pengukur ketebalan

- alat uji kekerasan

- alat uji tensile strenght

- Weather - Ometer CXW - 2

Metode Penelitian.

Dalam melaksanakan penelitian pengaruh cuaca terhadap sol karet cetak dengan mempergunakan alat Weather - Ometer CXW - 2, selama penelitian berlangsung alat diatur pada kondisi yang tetap dipertahan suhu pada black panel $50^{\circ} \mathrm{C}$, dry bulb $36^{\circ} \mathrm{C}$, wet bulb $26^{\circ} \mathrm{C}$ dengan kelembapan relatif sebesar $45 \%$. Pengaturan kondisi dengan cara menggunakan cam 7 pada bagian cycle program. setiap 2 jam sekali penyinaran akan terjadi hujan buatan selama 18 menit dengan tekanan penyemprotan air sebesar $18 \mathrm{psi}$.

Cuplikan yang diperlakukan dengan alat ini selama 150 jam, dengan interval pengambilan cuplikan tiap-tiap 25 jam sekali, yang selanjutnya diadakan pengujian sifat fisisnya yang berupa tegangan putus, perpanjangan putus dan kekerasan yang masing-masing dengan tiga kali ulangan. Data yang diperoleh dari hasil pengujian fisis selanjutnya dianalisa dengan menggunakan metode CRD.

Hasil Penelitian dan Pembahasan

Hasil uji fisis tegangan putus, perpanjangan putus dan kekerasan, sol karet cetak dengan melalui tiga kali ulangan dapat dilihat pada tabel berikut ini :
Tabel 1: Data-data hasil uji sifat fisis cuplikan

\begin{tabular}{|c|c|c|c|c|c|c|c|c|}
\hline \multirow{2}{*}{ No. } & \multirow{2}{*}{ Jenis uji } & \multicolumn{7}{|c|}{ Waktu perlakuan (jam) } \\
\cline { 3 - 9 } & & 0 & 25 & 50 & 75 & 100 & 125 & 150 \\
\hline \multirow{2}{*}{1.} & Tegangan & 119,21 & 102,25 & 96,80 & 87,12 & 73,33 & 66,08 & 62,58 \\
& putus, & 104,11 & 105,92 & 92,21 & 87,42 & 70,21 & 64,08 & 60,76 \\
& $\mathrm{Kg} / \mathrm{Cm}^{2}$ & 112,44 & 107,80 & 95,98 & 96,33 & 66,53 & 76,42 & 64,54 \\
2. & Perpan- & 233,95 & 187,80 & 182,9 & 166 & 155,6 & 122,2 & 180 \\
& jangan & 237,21 & 195 & 187,8 & 184 & 133,3 & 137,8 & 200 \\
& putus, \% & 230,23 & 163,41 & 170,73 & 218 & 144,4 & 166,7 & 192 \\
& Kekerasan & 70 & 65 & 65 & 64 & 64 & 64 & 70 \\
& 67 & 70 & 68 & 67 & 66 & 66 & 66 \\
& Shore A & 67 & 65 & 68 & 67 & 64 & 65 & 66 \\
\hline
\end{tabular}

Berdasarkan data hasil pengujian sifat fisis tersebut diatas dapat diketahui, adanya perlakuan cuplikan karena pengaruh cuaca terjadi perubahan sifat fisis dan perubahan ini cenderung menurun, bila dari data tersebut dibuat rata-rata maka hasil rekapitulasinya seperti terlihat pada tabel 2 berikut :

Tabel 2 Rekapitulasi rata-rata hasil uji sifat fisis cuplikan

\begin{tabular}{|c|c|c|c|c|c|c|c|c|}
\hline \multirow{2}{*}{ No. } & \multirow{2}{*}{ Jenis uji } & \multicolumn{7}{|c|}{ Waktu perlakuan (jam) } \\
\cline { 2 - 9 } & 0 & 25 & 50 & 75 & 100 & 125 & 150 \\
\hline 1. & $\begin{array}{c}\text { Tegangan } \\
\text { putus, } \\
\text { Kg/Cm2 }\end{array}$ & 119,92 & 105,32 & 94,99 & 90,29 & 70,02 & 68,86 & 62,63 \\
\hline $\begin{array}{c}\text { Perpan- } \\
\text { jangan } \\
\text { putus, \% } \\
\text { Kekerasan }\end{array}$ & 68 & 63,80 & 182,07 & 180,49 & 189,33 & 144,43 & 142,2 & 142,67 \\
\hline
\end{tabular}

Terjadinya perubahan sifat fisis terlihat lebih jelas lagi bila cuplikan yang berasa sol karet cetak disajikan dalam bentuk prosentase terhadap blankonya, sepert halnya terlihat pada tabel 3 berikut :

Vol. IX No. 16 Tahun 1993/1994
11 
Tabel 3 Prosentase perubahan sifat fisis dengan membandingkan terhadap blanko.

\begin{tabular}{|c|c|c|c|c|c|c|c|c|}
\hline \multirow{2}{*}{ No. } & \multirow{2}{*}{ Jenis uji } & \multicolumn{7}{|c|}{ Prosentase perlakuan (jam) } \\
\hline & & 0 & 25 & 50 & 75 & 100 & 125 & 150 \\
\hline 1. & $\begin{array}{c}\text { Tegangan } \\
\text { putus, } \\
\mathrm{Kg} / \mathrm{Cm}^{2}\end{array}$ & 119,92 & 105,32 & 94,99 & 90,29 & 70,02 & 68,86 & 62,63 \\
\hline 2. & $\begin{array}{c}\text { Perpan- } \\
\text { jangan } \\
\text { putus, \% }\end{array}$ & 233,80 & 182,07 & 180,49 & 189,33 & 144,43 & 142,2 & 142,67 \\
\hline 3. & Kekerasan & 68 & 67 & 67 & 66 & 65 & 65 & 67 \\
\hline
\end{tabular}

ari tabel tiga tersebut diketahui bahwa untuk sifat fisis yang berupa tegangan utus mengalami perubahan yang paling besar setelah cuplikan yang diperoleh ari sol karet cetak dikenakan perlakuan cuaca buatan selama 150 jam, demikian ıga halnya dengan perpanjangan putus perubahan lebih besar terjadi sesudah uplikan dikenakan perlakuan cuaca buatan selama 125 jam, adapun untuk keerasan bila dilihat secara keseluruhan juga mengalami perubahan dan perubahn terbesar terjadi pada cuplikan yang dikenakan perlakuan selama 125 jam pabila dari prosentase perubahan sifat fisis tersebut disajikan dalam bentuk rafik, maka dapat dilihat seperti berikut ini :

irafik prosentase perubahan sifat fisis cuplikan terhadap blanko :

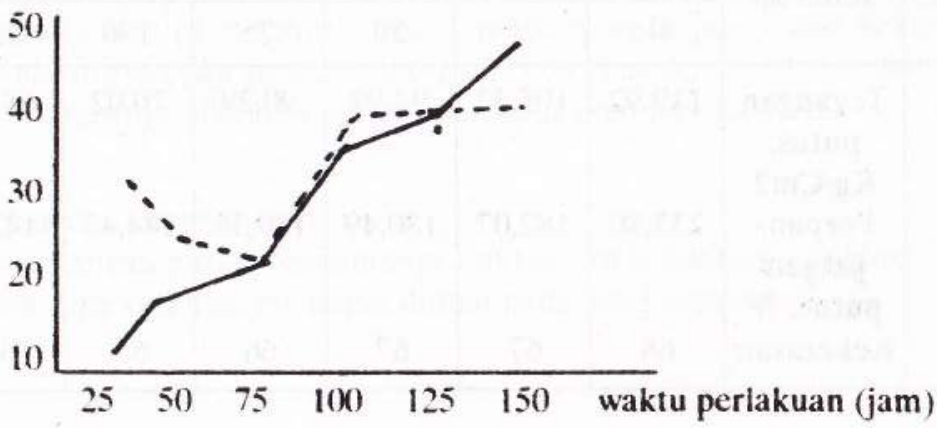

Ceterangan :

Tegangan putus :

Perpanjangan putus : ......
Untuk mengetahui apakah diantara perlakuan yang dikenakan pada cuplikan yang diuji berbeda nyata atau tidak, maka data hasil uji sifat fisis yang diperoleh lebih lanjut dianalisa secara statistik dengan metoda statistik completely randomized design, yang memberikan hasil sebagai berikut ;

Pada uji tegangan putus dari cuplikan yang dikenakan perlakuan cuaca dalam alat Weather - Ometer selama 25 jam tidak menunjukkan adanya perbedaan yang nyata terhadap blanko, demikian juga halnya dengan sifat fisis yang berupa kekerasan, tetapi untuk sifat fisis perpanjangan putus menunjukkan adanya perbedaan yang nyata terhadap blanko. Untuk cuplikan yang diperlukan dengan cuaca dalam alat yang sama selama 50 jam ternyata sifat tegangan putusnya berbeda nyata dengan blanko, sedangkan sifat fisis yang berupa perpanjangan putus dan kekerasan tidak berbeda nyata terhadap blanko. Pada cuplikan yang diperoleh dari sol karet cetak yang mendapat perlakuan cuaca dalam alat selama 75 jam hasil analisa statistik untuk tegangan putus dan kekerasan tidak memperlihatkan adanya perbedaan yang nyata dengan blanko, namun untuk sifat perpanjangan putusnya ada perbedaan yang nyata dengan blanko.

Untuk cuplikan yang diperlukan dengan cuaca dalam alat selama 100 jam pada tegangan putus dan perpanjangan putus tidak menunjukkan perbedaan yang nyata dengan blankonya, namun pada sifat kekerasannya berbeda nyata. Bagi cuplikan yang mendapat perlakuan cuaca dalam alat selama 125 jam dan 150 jam hasil analisa statistik menunjukkan pada uji tegangan putus dan perpanjangan putus tidak menunjukkan perbedaan yang nyata terhadap blankonya, namun demikian pada uji kekerasan untuk cuplikan yang dikenai perlakuan cuaca dalam alat tidak menampakkan perbedaan yang nyata dengan blanko untuk yang 125 jam, sedangkan yang memperoleh perlakuan selama 150 jam maka cuplikan mempunyai sifat kekerasan yang berbeda nyata dengan blanko.

Berdasarkan atas uraian tersebut diatas dapat diketahui bahwa pada uji tegangan putus dari enam macam perlakuan sekali diantaranya menunjukkan adanya perbedaan dengan blanko, sedangkan untuk uji kekerasan serta uji perpanjangan putus dari enam macam perlakuan dua diantaranya ada perbedaan yang nyata dengan blanko.

\section{Kesimpulan}

1. Cuplikan yang berasal dari sol karet cetak dan dikenakan perlakuan cuaca dalam alat Weather - Ometer mengalami perubahan sifat fisis dan perubahan tersebut cenderung menurun.

2. Dilihat dari prosentase perubahan sifat fisis terbesar pada tegangan putus setelah mendapat perlakuan $150 \mathrm{jam}$, sedangkan perpanjangan putus setelah 125 dan 150 jam, namun untuk kekerasan perubahan terbesar terjadi setelah

Vol. IX No. 16 Tahun 1993/1994 
cuplikan diberi perlakuan selama 100 jam dan 150 jam.

3. Dari hasil analisa statistik untuk sifat tegangan putus, perpanjangan putus dan kekerasan ada yang berbeda nyata serta ada pula yang tidak berbeda nyata dengan blanko.

\section{Daftar Pustaka}

1. Atlas electric device company, Instruction booklet number CXW-2, Type Weather-Ometer Chicago 1985

2. David Sinas, Weathering of polymer aplied science publishere 19.

3. Goori K John, Wiley, Statistical consepts and Methode, New-York 1977

4. Kluckous Paul Dr. Ing, Rubber and plastic, London chamanan and Hall 1965

5. Morton Maurice, Rubber technology, New-York

6. Small business publication, Rubber technology and manufacture, Delhi 